\title{
EDITORIAL
}

\section{On the inevitability of death}

Death is the possibility of the impossibility of any existence at all.

— Martin Heidegger, Being and Time (1962)

\section{STARING AT THE SUN TOO LONG}

It was one of those weeks when it was impossible to deny the inevitability of death. Like many of us who work in palliative care, I find it necessary to protect myself from time to time by denying death, in subtle ways, so as not to be overwhelmed by death and what many of us refer to as death anxiety or death terror. But this past week was just too overwhelming. The constancy and rapidity of a series of confrontations with death shared with patients combined with a series of deaths of close friends and family forced me to look away. I could not "stare at the sun," as Yalom (2008) wrote about the impossibility of confronting and contemplating death for too prolonged and sustained a period of time.

It had been brewing for some time, but last week was the tipping point. My ability to grapple with my own death anxiety, while working day in and day out with patients who were in despair about their mortality and the "nearness" and "reality" of their deaths from cancer, was being challenged on a regular basis. Age milestones, family milestones, and work milestones all conspired to penetrate any defenses I might have employed to deal with aging and the much-too-rapid passage of time. Even the deaths of celebrities who made up the cultural context of my life shook me: Robin Williams, Garry Shandling, and Mary Tyler Moore. How could they have died? I remember turning, one day recently, to my son and half-jokingly saying out loud, "If Don Rickles [a famous American comedian] can die, that means ANYBODY can die!" That revelation included an evaluation of the reality of my own fate and the stark inescapable reality of my own mortality.

I also can't underestimate the effect of the very recent death of one of my heroes and a pioneer in death-and-dying studies. Avery Weisman, a leading Harvard psychiatrist and director of the Omega
Project with Bill Worden in the 1960s, died at the age of 103. Avery taught us about "middle knowledge," a concept related to coping with death anxiety (Weisman, 1972). The concept of middle knowledge explicates the fact that denial of death is complex and often involves two simultaneously and opposite views of the inevitability of death. We can deny death and minimize the bleakness of one's prognosis with a terminal illness while simultaneously making plans for that death by completing a will, arranging burial plots, and planning a funeral service. This concept of middle knowledge was important for several reasons: it suggested the benefits of denial in preventing us from being overwhelmed by death terror, thus allowing us to assimilate and even accommodate the reality of our deaths at a manageable pace, and it suggested that human nature and biology utilize denial in complex ways that are not uniformly detrimental to the process of dying.

\section{ESCAPING DEATH}

I half-believed that Avery would never die—that he'd somehow escape the angel of death (who perhaps was on a vacation in Phoenix). I must confess that this "escaping death" fantasy seems to run in our family. When my son Sam was about 6 years old, I was reading him a bedtime story. He had just started going to Hebrew day school and was learning about Jewish culture and religion. He had been introduced to the concept of God, the omniscient and omnipresent biblical God who controlled everyone's life and destiny. Sam asked, "Dad, there are billions and billions of people in the world, right?" I replied, "Yes." Sam then asked, "and God has to keep track of each and every one of these billions and billions of people all the time, to figure out what happens to them and when they die?" "Yes, I suppose so." Sam finally came to the point: "So Dad, do you think, that with all those people to have to keep track of, God might actually lose track of me, and I might get to not have to die?" I was shocked and amazed but didn't show it. I had harbored the exact same fantasy, the 
same wish and hope, for most of my own childhood. Now here was my 6 -year-old son, the spitting image of me at his age, expressing the same fantasy, the same wish to never die and cease existing. Without skipping a beat I responded, "Sam, I think that's a real possibility. Maybe God can pass over both of us, and we can be together forever!" Sam smiled and let out a sigh of relief: "Yeah, Dad. That would be awesome, wouldn't it?"

In his Pulitzer Prize-winning "The Denial of Death," Ernest Becker (1973) taught us that in order for human beings to deal with the "terror of death" they created "cultures." Most of the early cultures were in fact religions, and they provided answers to questions about our origins, about the purpose of life, and about what happens after death. Most religions explain death as a continuation of life in a transformed state, and in a place where there is no longer death but immortality.

\section{DEFINING DEATH}

When thinking about or discussing death, it is useful to have a sense of what we mean by death, and that is not always a uniformly agreed-upon concept.

Is death loss of life or loss of existence?

Is death annihilation or a transformation of one's life or existence?

Death of humans is seen as a "natural" and essential part of life, comparable to the natural history of other life forms in nature, yet it is also seen by many religions as uniquely different in profound ways.

Death is often defined as the cessation of all the biological functions that sustain a living organism. One of the challenges in defining death is in distinguishing it from life. As a point in time, death would seem to refer to the moment at which life ends. Determining when death has occurred requires drawing precise conceptual boundaries between life and death. This is difficult due to there being little consensus on how to define life itself. This general problem applies to the particular challenge of defining death in the context of medicine. For example, brain death, as practiced in medical science, defines death as the point in time at which brain activity ceases. It is possible to define life in terms of consciousness. When consciousness ceases, a living organism can be said to have died. Another problem is in defining consciousness. Many religious traditions hold that death does not (or may not) entail the end of consciousness.

Death is the "possibility of the impossibility of any existence at all" according to Heidegger's Being and Time (1962). This can be interpreted as annihilation of existence (of mind, spirit, and body). Death as the annihilation of existence, disconnection from all life experience and loved ones, and the cessation of consciousness is at the essence of death terror. With advances in medicine and technology-particularly in the areas of precision genomic medicine, immunotherapy, cell therapy, transplantation, artificial organs, and cryonics-medicine has moved implicitly away from delaying death to the preclusion of death. In time, the "inevitability" of death will be a very real question. Death may in fact not be inevitable at all in the future. Interestingly, marketers and advertisers have moved their attention from selling to "millennials" to focusing on "perennials"-that's us, the generations that may live longer and possibly indefinitely. As opposed to generations whose lives were dominated by religious faith and concepts of an afterlife as a means of death denial, the postmodern world presents two choices to postmodern people. One is the promotion of a "death-denying culture," where mortal beings neglect or deny death with a "veil of ignorance" and a focus on youth and material goods and all that entails. The second choice is quite interesting to me and very relevant to the cultural and legal shifts that are now affecting palliative care globally. The second method of coping or minimizing the terror of death is to control death through legalization of practices aimed at self-determination and autonomy and control of the process and timing of death through legalizing physician aid in dying and euthanasia. Control over the timing and circumstances and processes of death seems to sufficiently allay our terror of "dying." But does it solve the problem of "nonexistence"? Or that of separation from or cessation of consciousness? Perhaps the acceptance of death necessary to choose physician aid in dying or euthanasia presumes that these issues have somehow been resolved.

\section{SO WE ALL DIE, BUT AT LEAST TODAY IT WASN'T YOU OR ME}

Sherwin Nuland (1993), the Yale surgeon, in an interview about his book "How We Die," said,

"To me, the hope that can exist at the time of death is the hope of our heritage, that we have really meant something to people, whether they are our own children or friends or students, whatever. That's the hope, the hope that your heritage is something good for others. And I think when you think of death as being part of the life cycle and recognize that death is an inevitability for our species because the world has to be renewed with each death, then the hope becomes that when it is renewed it will be renewed by people on whom I have had some influence for good." 
My mother had a ritual she practiced every time we attended a graveside funeral. Over the years, these ceremonies involved many friends and relatives, and then in later years closer and closer relativesgrandparents, aunts, uncles, a nephew, my father. My mother would do and say the same thing at each and every one of these events. After the burial, she would approach me, embrace me, and hold me very close to her so that she could whisper the following into my ear with no one else being able to overhear what she was saying: "Don't be afraid. Don't be afraid! Death is a normal part of life. It is the normal cycle of nature, of all living things. Everything, everyone lives and dies. Everyone! So it has to be okay because it is natural. Death is natural. It is inevitable." And then she'd add the following final note: "But at least today it wasn't you or me, my love." In 2010, when my mother died, and we as a family finished covering her casket inside her burial plot with earth, in typical Jewish tradition I sought out my son Sam. I embraced him and held him very close so that I could whisper the following into his ear with no one else being able to overhear: "Don't be afraid. Don't be afraid! Death is a normal part of life. It is the normal cycle of nature, of all living things. Everything, everyone lives and dies. Every- one! So it has to be okay because it is natural. Death is natural. It is inevitable." And then I added the following final note: "But at least today it wasn't you or me, my love."

\section{REFERENCES}

Becker, E. (1973). The Denial of Death. New York: Free Press.

Heidegger, M. (1962). Being and Time. Trans. J. Macquarrie \& E. Robinson. London: SCM Press.

Nuland, S.B. (1993). How We Die: Reflections on Life's Final Chapter. New York: Knopf/Random House.

Weisman, A.D. (1972). On Dying and Denying: A Psychiatric Study of Terminality. New York: Behavioral Publications.

Yalom, I.D. (2008). Staring at the Sun: Overcoming the Terror Death. New York: Jossey-Bass/Wiley.

WILLIAM BREITBART, M.D.

Editor-in-Chief, Palliative \& Supportive Care Chairman, Jimmie C. Holland Chair in Psychiatric Oncology Chief, Psychiatry Service, Department of Psychiatry \& Behavioral Sciences Memorial Sloan Kettering Cancer Center 641 Lexington Avenue, 7th Floor New York, New York 10022 E-Mail: Breitbaw@mskcc.org 